https://helda.helsinki.fi

\title{
The Expansion of Industrial Tree Plantations and Dispossession in Brazil
}

\section{Kröger, Markus}

2012-07-03

Kröger , M 2012 , ' The Expansion of Industrial Tree Plantations and Dispossession in Brazil pÿ' , Development and Change , vol. 43 , no. 4 , pp. 947973 . https://doi.org/10.1111/j.1467-7660.2012.01787.x

http://hdl.handle.net/10138/154654

https://doi.org/10.1111/j.1467-7660.2012.01787.x

acceptedVersion

Downloaded from Helda, University of Helsinki institutional repository.

This is an electronic reprint of the original article.

This reprint may differ from the original in pagination and typographic detail.

Please cite the original version. 


\title{
Markus Kröger. 2012. The Expansion of Industrial Tree Plantations and Dispossession in Brazil. Development and Change 43(4): 947-973. DOI: 10.1111/j.1467-7660.2012.01787.x
}

\author{
Post-print version. For original, and page numbers, please see:
}

http://onlinelibrary.wiley.com/doi/10.1111/j.1467-7660.2012.01787.x/full

\begin{abstract}
The recent expansion of tree plantations is the most important agrarian change in many parts of Brazil. This article uses the results of extensive field research to analyse the different ways paper and pulp companies assure their land base for eucalyptus plantations. The mechanisms of land access have changed little over the decades, amounting to a process of primitive accumulation which seems to be controlled by the ways the pulp industry influences land markets and prices, the strength of any resistance, and particularly the government support enjoyed by industry. Many paper and steel companies, either directly or indirectly, are increasingly relying on eucalyptus plantations, with negative impacts in many places. The expansion of tree monocultures with rural exclusion is characteristic of the wider phenomenon of land grab which is driven by the dominating financial logic of current capitalism.
\end{abstract}

\section{INTRODUCTION}

Brazilian agrarian change is playing an increasingly important role in global natural resource politics. ${ }^{1}$ Rising levels of natural resource extraction in Brazil, particularly the expansion of the export-oriented plantation economy, is pushing land cover changes, social changes and market transformations. An increasing proportion of the Brazilian territory is being used for industrial plantations, ${ }^{2}$ including trees, agrofuels and genetically modified soybean (IBGE, 2006a). In 1995, 41.8 million ha of Brazil's land area were used for fields (lavouras); in 2006, the figure was 76.7 million ha (ibid.). Much of the increase was from the expansion of industrial plantations, which covered 70.5 per cent of fields in 2006 (the rest being used by family farms) (IBGE, 2006b). Charcoal and pulpwood plantations use fast-wood forestry of eucalyptus trees (with a rotation of two to ten years) to produce fibre for charcoal and paper pulp production. ${ }^{3}$ In 2006, Brazil had over 3.5 million ha of eucalyptus plantations (Piketty et al., 2009: 181). By 2011, eucalyptus had expanded to cover more than 5 million ha, representing about 70 per cent of Brazil's total tree plantation cover of over 7 million ha (ABRAF, 2011: 44). Brazil will soon be the leading global exporter of chemical pulp, with the main destinations being China, the USA and Germany (Finnish Forest Industries Federation, 2009). The rising demand from China alone will maintain heavy pressure on Brazilian land, encouraging rapid eucalyptus expansion.

This article assesses the different mechanisms, the unifying logic and the consequences of the process by which tree plantations have expanded in Brazil. Most mechanisms are driven by the state-industry alliance, though mounting resistance since 2004 has started to influence the pace and style of expansion. The main argument presented here is that 'private' pulp corporations continue to expand largely because the state is providing them with land to do so, ${ }^{4}$ and that this land is being taken from users who have common or collective claims. There is evidence that the main process is characterized by primitive accumulation, or accumulation by

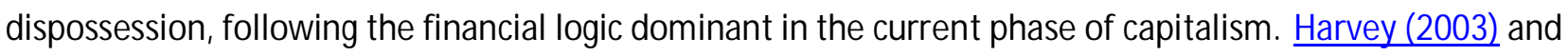


Sassen (2010) argue that M arx's primitive accumulation is still prevalent in the expanding resource frontiers of most extraction industries, and dispossession and financialization have become its central mechanisms. According to this theory, by expanding tree plantations over state, indigenous, peasant, afro-Brazilian and other publicly or commonly inhabited or uninhabited land, companies are able to seize zero-cost or low-cost land assets and turn them to private, profitable use. The state has largely preferred to provide land titles to key corporations rather than to smallholders. Corporate land access which directly or indirectly causes the exclusion of poor, non-documented tenant farmers and rural populations that comprise indigenous, extractive and other traditional communities - which are then fenced off from these lands - can be characterized as accumulation by dispossession.

The findings on which this article is based are the result of extensive field research between 2004 and 2011, involving representatives of all relevant actors in the pulpwood plantation expansion or its resistance in Brazil. $\frac{5}{}$ The research included extensive participant observation and 150 semi-structured interviews with key informants (twenty-one public officials, twenty-four pulp industry representatives, ten medium- or large-scale contract farmers of eucalyptus, and ninety-five activists and/or rural dwellers), enabling the author to see such expansion in practice and to ask questions about how it has taken place. The methods included ethnography and triangulation through systematic comparison of established areas and emerging 'frontiers' of eucalyptus cultivation. The goal of the article is to present, as holistically as possible, the central correlations and causal relationships operating in this expansion. For this, both statistical inference and qualitative analysis are used, going through the entire body of interviews and primary material, and analysing the dominant themes, patterns, exceptions and contradictions in order to explore and explain the causes and consequences of eucalyptus expansion.

\section{TREE MONOCULTURES AND RURAL EXCLUSION}

\section{Primitive Accumulation}

With the concept of primitive accumulation, M arx illustrated a process of 'taking land, say, enclosing it, and expelling a resident population to create a landless proletariat, and then releasing the land into the privatized mainstream of capital accumulation' (Harvey, 2003: 149). Harvey (ibid.: 145) summarizes the classic mechanisms of primitive accumulation:

These include the commodification and privatization of land and the forceful expulsion of peasant populations; the conversion of various forms of property rights (common, collective, state, etc.) into exclusive private property rights; the suppression of rights to the commons; the commodification of labour power and the suppression of alternative (indigenous) forms of production and consumption; colonial, neo-colonial, and imperial processes of appropriation of assets (including natural resources); the monetization of exchange and taxation, particularly of land; the slave trade; and usury, the national debt, and ultimately the credit system as radical means of primitive accumulation.

Harvey redefines the process as 'accumulation by dispossession', given that the mechanisms of primitive accumulation have changed: 'Some of the mechanisms of primitive accumulation that Marx emphasized have been fine-tuned to play an even stronger role now than in the past ... above all we have to look at the speculative raiding carried out by hedge funds and other major institutions of finance capital as the cutting 
edge of accumulation by dispossession in recent times' (ibid.: 147). New mechanisms, such as the patenting and licensing of genetic material and wholesale commodification of nature in all its forms, are typical of accumulation by dispossession.

The alternative is accumulation without dispossession (see Arrighi et al., 2011; Hart, 2002), in which domestic markets expand, reproduction costs decrease, and the quality of the labour force is raised by rural development and industrialization that do not drive people off the land; classic examples are China and some East Asian countries. ${ }^{-}$A forestry-based example is found in the decentralized agroforestry system in the Nordic countries, where forests - which are mostly not monoculture tree plantations but include multiple species are owned predominantly by a wide array of families (see Kuisma et al., 1999; Nylund, 2009).

Harvey (2003: 145-6) argues that the primitive accumulation identified by Marx is still powerfully present, as 'many formerly common property resources, such as water, have been privatized (often at World Bank insistence) and brought within the capitalist logic of accumulation' and 'family farming has been taken over by agribusiness', especially in the global South. For Sassen (2010: 25), the focus of the current logic of capitalism is not "the "valuing" of people as workers and consumers, but the expulsion of people and the destruction of traditional capitalisms to feed the needs of high finance and the needs for natural resources'.

Sassen's point on labour/ capital has recently been confirmed and strengthened by Li's (2011) work on 'recentering labour in the land grab debate'. Li's labour perspective highlights the lack of jobs generated, illustrating that large-scale land acquisition, promoted by the World Bank and many governments, is unlikely to result in poverty reduction: 'In much of the global South, the anticipated transition from the farm to factory has not taken place and education offers no solution, as vast numbers of educated people are unemployed' (Li, 2011: 281). Agribusiness expansion 'excludes' traditional rural communities from customary land rights (and thus jobs), intensifies the power of financial capital, and in the best case, only leaves conditional options for 'incorporation' (Li, 2011; Sassen, 2010). Far larger numbers of people are 'expelled' than 'incorporated', however. The expansion of eucalyptus plantations and the simultaneous dispossession and curbing of agrarian reform in Brazil is a case in point.

\section{Dispossession}

Between the 1960s and 1980s, tree plantation companies acquired Brazilian land through harsh means. In many regions, the land access mechanisms depicted in a M inistry of the Environment report are still common:

Before the company establishes itself in the region, men arrive wearing the clothes of rich farmers, driving pickups and wanting to buy land from small producers. Even though it was argued that there were no cases of death or explicit physical violence, the non-articulation and non-organization of local farmers put them into too vulnerable a position to take an informed decision. (M MA, 2005: 37)

Since its establishment in 1975, the Pastoral Land Commission (CPT) has extensively documented both indirect and direct brutal rural violence (including murders, slavery, criminalization of resistance and deprivation of livelihoods) inherent in (tree) plantation expansion. ${ }^{7}$ For example, in the state of Amapá, the court found Champion, a company exporting trees for pulp production, guilty of acquiring land illegally, using grileiros and 
extortion (M MA, 2005: 37). ${ }^{-}$Some of these accounts led to the transfer of tree plantation lands back to traditional communities.

In the states of Pará, Amapá and Maranhão, particularly, plantations destined to produce pulp or charcoal drove ancient communities and small-scale farmers from their lands. A Parliamentary Investigation (CPI) ${ }^{9}$ in 2004 recommended that 370,000 ha of state land occupied by the eucalyptus plantations of the multinational corporation Jarí Celulose be parcelled and distributed to subsistence farmers in an attempt to resolve the land conflicts resulting from massive dispossession (M M A, 2005: 40). During the 1960s and 1970s, the Jarí Project in Brazil invaded indigenous land, 'like most other M NCs' (Arruda et al., 1975: 164). This occurred all around the world, not just in Brazil; as Marchak (1995: 14) alleges 'where there are still indigenous peoples, both forestry in natural stands and plantations deprive them of land. Typically, they are dispersed or pushed to the margins of the forest'. According to the North American Congress on Latin America (NACLA), the company Aracruz Celulose in Espírito Santo:

Illegally appropriated land from the Tupinikim and Guarani, building its first factory in an aldeia called Macacos. This was easy, since there were no formal registers of indigenous populations or their lands. M oreover, the corporation had the full support of municipal, state, and federal governments, and was able to acquire land through a variety of ways, including grilagem, or falsifying deeds. (Kenfield, 2007: 10)

During the military dictatorship (1964-84), pulp companies such as Aracruz enclosed peasant, Indian and Quilombo lands, driving communities out of forests (Ferreira, 2009; M yllylä and Takala, 2010). This has left a legacy of complex land conflicts surrounding contemporary pulp businesses in the places where rural populations were displaced and where resistance movements have managed to mobilize and bring their grievances to public knowledge (Kröger, 2011). These conflicts are the result of both predatory schemes and latent conflicts given impetus through the introduction of forest companies into the areas.

Illegal land grabbing, or grilagem, is a commonly used mechanism for creating private property in Brazil, particularly in the 'pioneer' frontiers where capitalism expands into 'Deep Brazil': many military government officials supported and/or used it as an unofficial tool for creating large-scale properties for themselves or others (Asselin, 2009). All of the ninety-five activists interviewed, as well as two of the ten contract farmers and eleven of the twenty-one public officials, suggested that pulp companies accessed land through grilagem which led to dispossession. None of the twenty-four pulp industry representatives interviewed said directly that companies would have used grilagem, even though firms (such as Veracel) which have been caught planting on community lands have claimed they were unaware of having bought land illegally grabbed previously by the seller (Kröger and Nylund, 2012). Ferreira (2009) has done extensive and well-documented research in notary offices in Espírito Santo showing in detail how communal land ended up in the hands of Aracruz via grilagem. Another example is the new Suzano pulp venture at Imperatriz in the Eastern Amazon state of Maranhão that used a thickly forested land populated by indigenous and traditional communities (now mostly deforested) to expand its eucalyptus plantations within a land grab trajectory that started in the 1970s (author's fieldwork, spring 2011). The "grilagem arrived as the best instrument of [capital's] domination, turning the so-called "free" lands into capitalism's privileged means of incorporation' (Asselin, 2009: 29). Multilateral agencies and governments have supported this process by offering extensive incentives for plantations. 
Governments have also controlled who is defined as a 'landowner' or a 'squatter', and the procedures by which one could 'legally' ratify a landholder status; the Quilombo and Indigenous populations living in forests were in the worst position to be able to defend their case. The forest land they used was seized at zero cost by companies backed by governments. To prevent this from happening, the communities would have had to demarcate and register their lands in notary offices, and the state Department of Lands and Cartography would have had to approve their claims. In Espírito Santo, for example, the state was much more inclined to name the community lands as 'unused' (devoluta), and thus state land, available to be given to Aracruz. This was a form of juridical expropriation, an institutionalized and legalized grigalem (Ferreira, 2009).

While similar effects were visible with other forms of agricultural expansion, the creation of a tree plantationbased paper industry was a key developmental goal of the military dictatorship (Kröger and Nylund, 2012), and the role of the state was more prominent. Whereas cattle ranch expansion on the northern pioneer frontier was often organized by private farmer groups from the south (Jepson, 2006), 10 eucalyptus expansion was more clearly a state-led project. The dispossession was therefore more complete, leaving fewer or no clear channels for resistance: state institutions - the last resort for claims - were not impartial. For example, during the dictatorship, the state of Espírito Santo created the Institute of Agroforestry Development (IDAF) to oversee the process. In spite of requests by the National Institute of Colonization and Agrarian Reform (INCRA) and indigenous movements, IDAF has not opened up its archives to explain how devoluta lands were defined (Ferreira, 2009).

\section{EUCALYPTUS PULP AND DEVELOPMENT}

Eucalyptus monoculture-based pulp investments started being planned in the 1960s by government-industry alliances and powerful agents in the globalizing political economy, such as the World Bank, the Food and Agriculture Organization of the United Nations (FAO) and forest industry corporations (Carrere and Lohmann, 1996). The global capitalist setting in which eucalyptus monocultures surged is arguably a post-colonial legacy.

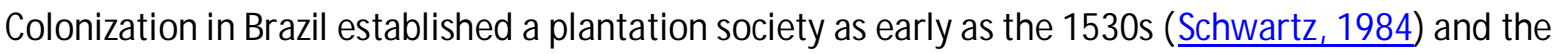
relationships forged through plantation hierarchies continue to dominate much of rural society today. Inequality, poverty, maldevelopment and violence were exacerbated by the opening up of the Brazilian economy to foreign markets through rapid neoliberalization in the 1990s and the increasingly fierce penetration of Brazilian capital into a global agro-industrial market. Within the forestry sector, global investors seeking maximum profit have, since the 1990s, become influential actors in financing forest trade, resulting in extremely streamlined pulp plants (Lehtinen, 2002). Cheap transportation costs, $\frac{11}{\underline{1}}$ efficient tree plantations, $\underline{\underline{12}}$ and liberal globalization and legislation $\underline{\underline{13}}$ meant Brazilian pulp producers reaped high profit margins, had extremely low cost structures, and captured global pulp markets: this can be seen in the companies' annual reports..$^{14}$ Growing demand, low costs and lack (or flexibilization) of regulation promoted the unrestrained expansion of eucalyptus, although in some cases public officials and movements have managed to slow down the pace of this expansion (Kröger, 2011).

Tree plantation expansion often directly challenges local pro-poor agrarian reform programmes and movements, and is conflictive (Gerber, 2010), especially where rural population density is high, livelihoods are tied to land, and peasants are organized (Kröger, 2011). Brazil boasts a mosaic of rural population histories,

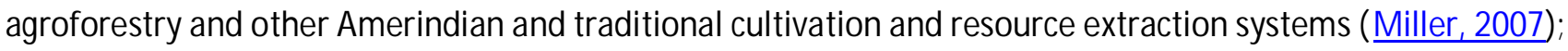


this is rapidly changing as monoculture expands, commoditizing and homogenizing the countryside, pushing an agribusiness system that does not create jobs but is capital intensive (Brandão, 2007). In 1985, agriculture employed about 23.4 million Brazilians; by 2006 this figure had dropped to only 16.5 million (IBGE, 2006a). Eucalyptus plantations and large-scale pulp projects not only create fewer jobs, but also offer fewer economic synergy benefits than agriculture or other industries (De'Nadai et al., 2005; Teixeira and Guerra, 2000). Yet, expansion of industrial tree plantations (ITPs) has been closely correlated with state support.

The developmental impacts of this state policy are mixed and subject to debate (see Kröger and Nylund, 2012 for an analysis). On the one hand, pulp export brings hard foreign currency, vital for the trade balance, and massive investment increases nominal GDP; new plants provide up to 8,000 jobs during capacity construction phase, which lasts about two years; and the industry fosters the establishment of machinery factories in the industrial centre of São Paulo. However, once pulp mills are in operation, there are few jobs on offer, making the cost per created job and per used hectare very high (De'Nadai et al., 2005). M oreover, the possibilities for small-scale farming and related commerce and agro-industry development are curbed as land is concentrated on ITPs. The amount of tax paid is very limited (10ly, 2007), but huge burdens are placed on the infrastructure of rural municipalities by the needs of dispossessed populations; their inability to cope leads to marginalization, crime and other socio-environmental and political problems due to a skewed power structure (Carrere and Lohmann, 1996; Souza and Overbeek, 2008).

Eucalyptus plantations also have a strong environmental impact. The decision by the forest industry to focus on plantations rather than on natural forests has led to major transformations in the socio-economic and environmental landscapes in many rural areas of the global South (Marchak, 1995), including Brazil. In many cases, ITPs damage soil and regional water balances (see, for example, Carrere and Lohmann, 1996; Lackson et al., 2005; Koopmans, 2005) - qualities which are typically enhanced by natural forests. Calling tree monocultures 'forests', as is common within the industry, can hide the real lack of nature in industrial tree plantations (see Scott, 1998 for a discussion).

\section{BRAZIL'S INDUSTRIAL FORESTRY POUCY}

The working model of policy makers in developing the forest industry sector is clearly stated in a National Development Bank (BNDES) report as a cooperation between state, multinationals and national investors: 'In the $60 \mathrm{~s}, 70 \mathrm{~s}$ and $80 \mathrm{~s}$, BNDES was an instrument guaranteeing the triple alliance between state, multinationals and national private investors. The planning, the follow-up and the financing of the pulp and paper industry by

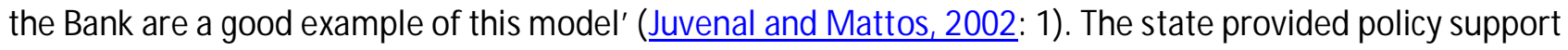
through national forestry and pulp and paper industry plans, legislation and other regulative structures and, above all, through access to credit on relatively easy terms (Bull et al., 2006). ${ }^{15}$ Plans were put into operation by favoured companies, and local capital and entrepreneurs dominated the process. The Brazilian constitution has contradictory clauses on land property: environmental and land agencies execute policies that are at odds with each other, and peripheral areas, especially, do not offer effective property rights (Puppim de Oliveira, 2008). In many cases, if companies (many partly or fully state-owned) contravened laws, it was as a result of carrying out specific government policies. The establishment of ITPs was essentially 'free' and even had the potential to provide a net gain: due to fiscal incentives, the rate of return for landowners planting eucalyptus was 663 per cent (assuming zero land cost) (Bull et al., 2006: 19, 25-6). ․ㅡ During this period, governments were offering 
pulp companies 'subsidies for start-up costs, taxation incentives, land grants, and relaxation of labour laws and other legislation' all around the world (M archak, 1995: 15), and Brazil was no exception. This led to wasteful expansion; 2 million of the 6 million ha planted during the military dictatorship proved commercially unusable (Bull et al., 2006), exacting heavy opportunity costs to local populations fenced off from the land.

The Center for International Forestry Research (CIFOR) argues that incentives to the paper industry led to market distortions and ecological hazards: 'Subsidies led to a greater concentration of land ownership and an increase in deforestation' (Cossalter and Pye-Smith, 2003: 38). According to the Brazilian M inistry of the Environment (MMA, 2005: 52), ${ }^{17}$ the military government imposed the industrial plantation model with an iron hand, and 'all attempts to rectify the situation were treated with the same formula of ignore-deny-suffocate'. Under the dictatorship, especially the Geisel government, rural development was based on large enterprises. This removed 'petty production units, intensifying the proletarianisation of the Brazilian countryside and, simultaneously, marginalising a large sector of the rural population' in a labour-transforming process in which the pulp entrepreneurs (such as the Norwegian Lorenzen of Aracruz, and Jarís owner, the American Daniel Ludwig) played 'an important role as a corporate agent' (Arruda et al., 1975: 185).

Brazil's governments have continued to pursue a macroeconomic policy in which developmental projects are focused on resource exports. In 2009, the BNDES lent US\$ 69 billion, most of it going to the developmental projects of large corporations - an amount that far exceeded the World Bank loanbook (The Economist, 2010). BNDES financing has been the main force behind the highly capital-intensive pulp projects that have territorialized Brazil with such vigour since the late 1990s. Eucalyptus plantations require higher investments than the expansion of other industrial crops (Fingerl and Filho, 1998): a new million-ton pulp investment costs over 1 billion euros, while plantations cost 250-300 million euros. As a result, establishing production capacity is largely dependent on available state financing. Brazilian pulp entrepreneurs are in a privileged position (Kingstone, 1999: 234-5). Figure 1 shows the finance provided by the Brazilian government-controlled BNDES to the paper and pulp industry (BNDES, 2009),, and the annual expansion of eucalyptus plantations destined for pulp production (Bracelpa, 2009). ${ }^{19}$ Particularly since 2000, the dramatic expansion of eucalyptus plantation lands is parallelled by the surge of state funding: there is co-movement over time between state funding and expansion.

Figure 1. The Correlation of State Financing and Pulp/Eucalyptus Plantation Expansion per Year (1996-2007) 

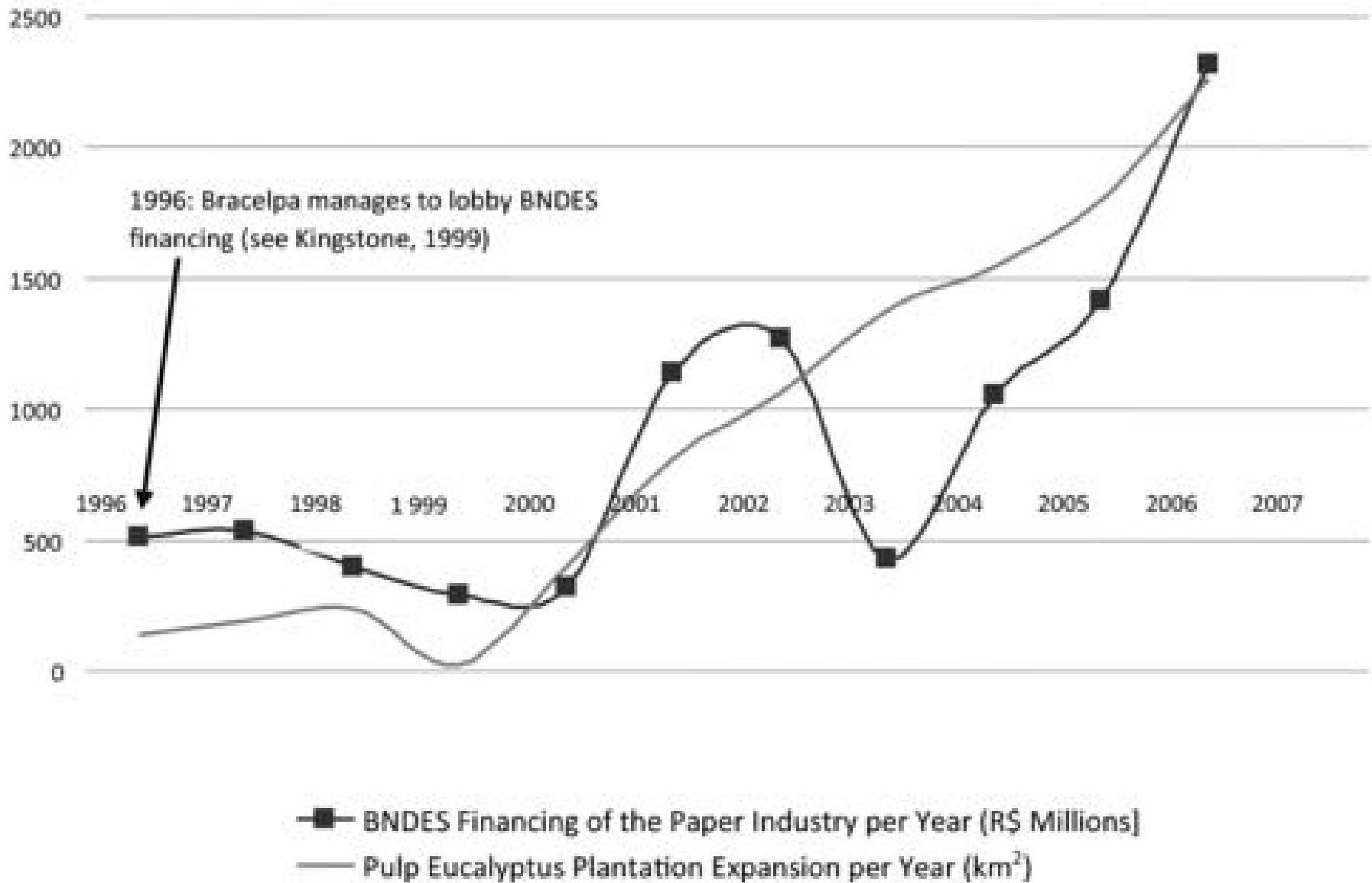

Notes: Values on the y-axis are nominal; BNDES credits are shown in millions of reais; plantation expansion is shown in $\mathrm{km}^{2}$. Sources: For financing, BNDES (2009); for plantation expansion, Bracelpa (2009).

Pulp investments using fast-wood eucalyptus normally manage to repay BNDES loans in record time (four to eight years), so financially it makes sense to invest in the expansion. BNDES provided half of the investment credits for Bahian Veracel Celulose and most of the credit for founding the new pulp giant Fibria, which enabled Votorantim Celulose e Papel (VCP) to buy Aracruz in 2009. $\underline{20}$ The state-financing of 'Big Pulp' is in line with the general political economic strategy of Brazil (Kröger, 2012). Lessa (2010), a prominent Brazilian economist and former BNDES president, argues that Brazil's economic stability in the past decade is principally based on the high prices of commodities. Structural questions such as extreme inequality are not discussed or addressed and the private sector is dominated by a rentier oligarchy that is neither interested nor willing to invest its own money, and therefore looks for speculative state-backed opportunities. These are all signs of the dominance of the financial logic of accumulation by dispossession in the current phase of Brazilian capitalism, which will be confirmed in the following broadly systematic and more detailed analyses of the data.

\section{SYSTEM ATIC COM PARISON ACROSS STATES}

The best data available from state, industry, civil society and research institutes have been collected in Tables 1 and $\underline{2}$, allowing us to draw statistical inferences and assess correlations and anomalies across the major 
eucalyptus pulp producing states. In Table 1, corporate land access types were divided into owned, rented/partnership, and outsourced, to see if these different forms show any relation to signs of primitive accumulation in areas of states where eucalyptus pulp plantations expanded in 2004-10. The numbers include only eucalyptus plantations of pulp companies, not those of other industries or plantations of other tree species. Table 1 also shows the relationship between land price and dispossession, based on general state-level data on land prices and displacement. $\underline{21}$

Table 1. Land Access Type, Land Price, and Dispossession, 2006-10

\begin{tabular}{|c|c|c|c|c|c|}
\hline State & \multicolumn{3}{|c|}{$\begin{array}{l}\text { Planted area ('000 ha) by corporate land } \\
\text { access type in 2009: a) Owned, b) Rented, c) } \\
\text { Outsourced }^{1}\end{array}$} & $\begin{array}{l}\text { Average price of } \\
\text { pasture land in 2006, } \\
\text { reais per ha }{ }^{2}\end{array}$ & $\begin{array}{l}\text { Families } \\
\text { all land } \\
2010^{3}\end{array}$ \\
\hline Bahia & 369 & 9 & 121 & 1,297 & 4,327 \\
\hline Espírito Santo & 129 & 1 & 41 & 3,882 & 1,335 \\
\hline Maranhão & 47 & 0 & 0 & 184 & 13,071 \\
\hline $\begin{array}{l}\text { Mato Grosso } \\
\text { do Sul }\end{array}$ & 89 & 65 & 1 & 1,613 & 784 \\
\hline M inas Gerais & 155 & 16 & 49 & 3,100 & 2,457 \\
\hline Pará & 48 & 0 & 1 & 601 & 9,225 \\
\hline Paraná & 51 & 12 & 45 & 5,900 & 585 \\
\hline $\begin{array}{l}\text { Rio Grande } \\
\text { do Sul }\end{array}$ & 150 & 17 & 19 & 3,128 & 111 \\
\hline São Paulo & 224 & 88 & 58 & 7,500 & 1,646 \\
\hline Total & 1,286 & 211 & 340 & & \\
\hline
\end{tabular}

Notes and sources:

1. Data on pulpwood extension and ownership-type in '000 ha on 31 December 2009 (source: Bracelpa, 2010: 12). Only states with more than 16,000 ha of eucalyptus plantations were included in the analysis.

2. Source: Gasques et al. (2008: 9). 
3. Includes all conflicts involving dispossession, expulsion, shootings, and takeover of capital, ITP and non-ITP related (source: $\underline{\text { CPT, 2011). }}$.

Table 1 shows a correlation between low land prices and higher displacement of families by land conflicts: the three states with the highest displacement in 2010 (M aranhão, Pará, Bahia, in bold in Table 1) had the lowest pasture land prices in 2006. According to the pulp companies, most eucalyptus expansion was onto former pasture lands: as companies moved into the peripheries with low land prices, rural families with unclear land tenure relations have been pushed, directly or indirectly, off the lands. Higher land prices, on the other hand, which are a sign of less peripheral settings, act as a barrier against accumulation by dispossession, which is, by definition, interested primarily in seizing control of assets at zero or low cost (Harvey, 2003). Paraná is an example of high land prices and relatively low expulsion rates; the process is happening there as well, but to a lesser degree. The limited primitive accumulation in Paraná also correlates with the distribution of corporateowned and rented/outsourced eucalyptus land (in bold): this is the state in which access is most equally distributed between the three categories (52 per cent of total eucalyptus land is rented or outsourced, the rest is corporate-owned), signifying that revenues from sold wood or land use are more equally distributed.

$\underline{\text { Table } 2}$ reduces the information in Table 1 into one column, labelled 'accumulation by dispossession' (ABD), which is the price of land divided by the number of families dispossessed: the lower the number, the higher the $A B D$ in the state. The $A B D$ is then compared with the nature of the dispossession, in terms of the presence (or absence) of typical signs of ABD in the eucalyptus pulpwood areas of that state. Fieldwork observations on five central and illustrative traits of primitive accumulation by eucalyptus expansion were coded in as columns in the Table (yes or no signifying their existence or not): occupation of agrarian reform lands/ expulsion of peasants; planting on indigenous or afro-Brazilian territories; killing of or violence against rural people directly linked to companies and the police (at times directly financed by the pulp companies); depletion of communal water resources by eucalyptus plantations; and replacement of native vegetation (forests, cerrado, pampa) by plantations. The particular indicators for each observation are listed in footnotes.

Table 2 shows that M aranhão (ABD 0.014), Pará (ABD figure 0.065) and Bahia (0.299) are the states where accumulation by dispossession has been most common: the land prices have been the lowest and the number of dispossessed families the highest. Next follow Minas Gerais, M ato Grosso do Sul, Espírito Santo and São Paulo, with ABD figures ranging from 1.261 to 4.556. Paraná (10.085) and Rio Grande do Sul (28.180) are in a rank of their own, with the least sign of general accumulation by dispossession. It is interesting to compare these figures with the pulp conflicts. Fieldwork and interviews revealed that in the latter two states, the landless movements were mostly attracting people from the cities'favelas as there were no longer many rural dwellers. In Rio Grande do Sul, disputes were centred on trying to occupy large tracts of unused latifúndio farms to push for direct action land reform where INCRA is forced to establish agrarian reform settlement before a pulp company could buy the same land tract for eucalyptus planting. However, the other, more specific signs of dispossession were present in pulp conflicts, particularly in the form of pre-emptive enclosure of suitable land and the use of violence against activists. 
Table 2. Accumulation by Dispossession, and Signs of Eucalyptus Pulp Expansion-related Dispossession in Brazil (Yes or No), 2004-10

\begin{tabular}{|c|c|c|c|c|c|c|}
\hline \multirow[b]{2}{*}{ State } & \multirow[b]{2}{*}{$\begin{array}{l}\text { Accumulation by } \\
\text { Dispossession (the } \\
\text { lower the figure, the } \\
\text { higher the ABD in } \\
\text { the state in general) }\end{array}$} & \multicolumn{5}{|c|}{ Nature and Existence of Dispossession in Pulp Investment Areas } \\
\hline & & $\begin{array}{l}\text { Planting on Peasants } \\
\text { expelled/agrarian } \\
\text { reform land occupied }\end{array}$ & $\begin{array}{l}\text { indigenous } \\
\text { or afro- } \\
\text { Brazilian } \\
\text { territories }\end{array}$ & $\begin{array}{l}\text { Killing of / } \\
\text { violence } \\
\text { against } \\
\text { rural } \\
\text { people }\end{array}$ & $\begin{array}{l}\text { Water } \\
\text { depletion } \\
\text { next to } \\
\text { eucalyptus }\end{array}$ & $\begin{array}{l}\text { Plantation } \\
\text { replaced } \\
\text { native } \\
\text { vegetation }\end{array}$ \\
\hline Bahia & 0.299 & Yes $^{1}$ & $\mathrm{Yes}^{2}$ & $\mathrm{Yes}^{3}$ & $\mathrm{Yes}^{4}$ & Yes $^{5}$ \\
\hline $\begin{array}{l}\text { Espírito } \\
\text { Santo }\end{array}$ & 2.907 & Yes $^{6}$ & Yes $^{7}$ & Yes $^{8}$ & Yes $^{9}$ & Yes $^{10}$ \\
\hline M aranhão & 0.014 & Yes $^{11}$ & Yes $^{12}$ & $\mathrm{No}^{13}$ & No & Yes $^{14}$ \\
\hline $\begin{array}{l}\text { Mato } \\
\text { Grosso do } \\
\text { Sul }\end{array}$ & 2.057 & Yes $^{15}$ & No & No & No & No \\
\hline $\begin{array}{l}\text { Minas } \\
\text { Gerais }\end{array}$ & 1.261 & Yes $^{16}$ & Yes $^{17}$ & Yes $^{18}$ & Yes $^{19}$ & Yes \\
\hline Pará & 0.065 & $\mathrm{Yes}^{20}$ & Yes $^{21}$ & No & No & Yes \\
\hline Paraná & 10.085 & $\mathrm{No}^{22}$ & No & No & No & No \\
\hline $\begin{array}{l}\text { Rio Grande } \\
\text { do Sul }\end{array}$ & 28.180 & Yes $^{23}$ & No & Yes $^{24}$ & Yes $^{25}$ & Yes $^{26}$ \\
\hline São Paulo & 4.556 & $\mathrm{Yes}^{27}$ & No & No & $\mathrm{Yes}^{28}$ & No \\
\hline
\end{tabular}

Notes and sources:

1. Responsible companies Veracel, Fibria and Suzano; location extreme south of Bahia; thousands of peasants expelled and agrarian reform impeded (Kröger and Nylund, 2012).

2. Veracel planted on Pataxó indigenous lands near the Monte Pascoal (author fieldwork, 2004-11).

3. A Quilombola man killed by the armed security force of Fibria in 2010.

4. Source: Koopmans (2005). 
5. Thousands of hectares of Atlantic rainforest cut down by Veracel (ex-Veracruz) in the 1990s (Fase et al.,1993).

6. Responsible company Fibria (ex-Aracruz); author fieldwork 2004-9; see also De' Nadai et al. (2005); MM A (2005).

7. M ore than 8,000 Quilombola families expelled by Aracruz, 1970s-2005; tens of thousands of hectares of indigenous land occupied by Aracruz (Ferreira, 2009).

8. Indigenous people beaten by police at the orders of Aracruz (thirteen were wounded in 2006); Quilombos mistreated by the police (Ferreira, 2009; http://www.cddh.com.br).

9. Source: Ferreira (2009).

10. Massive destruction of rainforest since the 1970 s by Aracruz (MMA, 2005).

11. M ain company Suzano, located in the Imperatriz and Baixo Parnaíba regions; observation of peasant exodus and agrarian reform impediment during fieldwork (March 2011).

12. Afro-Brazilian territories occupied by Suzano (author fieldwork, March 2011; see also Barros, 2008).

13. Suzano was not involved in this activity, according to fieldwork (March 2011). The 'no' in this and other cases does not necessarily signify that no such events have occurred; it means that nothing was observed in the field or reported in the material covered in this research.

14. Rural population and state authorities reported Suzano would be cutting rainforest in some places.

15. Pulp expansion and agrarian reform impediment at Três Lagoas, main companies Fibria, International Paper (Kudlaviz, 2011) and Eldorado Paper under construction, owned by JBS-Friboi, a Brazilian meat company.

16. Main companies Cenibra and International Paper; over $60 \%$ of the state's municipalities have long had tree plantations, with severe land conflicts related to rural exodus (M MA, 2005: 118-68).

17. Quilombos expelled (see MMA, 2005).

18. Slavery, child labour and other drastic violations of human rights still exist in the tree plantations of Minas Gerais (though mostly on charcoal plantations) (MMA, 2005: 118-68).

19. Source: MMA (2005).

20. The parliament recommend that company Jári, located at the border with Amapá state, return 370,000 hectares of occupied lands to communities (M MA, 2005: 39).

21. Jári planted on indigenous lands (MM A, 2005).

22. The data did not reveal that Paraná would have had considerable expulsion of peasants by pulp eucalyptus in the past years; the main company is Klabin, and its mills are small-scale. 
23. Tens of thousands of hectares of agrarian reform land (already marked by state authorities) occupied together by Aracruz and Votorantim (now Fibria) and Stora Enso; expansion located in the southern half of the state (pampa).

24. Killing of a landless movement activist in 2009 by police in a conflict with Aracruz; beating of demonstrators by police in 2008 by Stora Enso; orders of eviction (author fieldwork 2008-9; see also Kröger, 2011).

25. Fieldwork observations (2008).

26. Planted eucalyptus on fragile pampa areas (fieldwork observation, May 2008; also M iola, 2010).

27. Several communities displaced; agrarian reform made difficult; plantations located close to the state capital (MMA, 2005).

28. Source: MMA (2005).

Within the pulp industry, Bahia, Espírito Santo and M inas Gerais show the strongest signs of primitive accumulation, with all five sub-categories of the process active during the observation period. Expansion by pulp companies in Rio Grande do Sul, Pará and M aranhão showed mid-range primitive accumulation, with three or four of the five signs observable. Even though high in general ABD terms, M aranhão and Pará did not experience notable pulp plantation expansion between 2004-10, which may explain why only three of the five specific signs of pulp-related dispossession were present. However, the situation has changed since 2010, with massive new investment in Maranhão (and the neighbouring states) by Suzano. In São Paulo two signs were active, in Mato Grosso do Sul one, and in Paraná none. These three states also have a more balanced distribution of corporate access between owned, rented/partnership/ outsourced plantations (39 per cent, 42 per cent, and 52 per cent, respectively) than the states where more numerous signs of primitive accumulation were observed (Bahia $=26$ per cent of total eucalyptus land rented or outsourced; Espírito Santo $=24$ per cent; M inas Gerais $=29$ per cent). This suggests a correlation between corporate land concentration and primitive accumulation and dispossession.

Dispossession was influenced by the large-scale investment style and by context. In the states with fewer signs of primitive accumulation, the context of plantation expansion was important: in these areas, there were fewer (or no) indigenous and afro-Brazilian communities to dispossess, and less native vegetation to be replaced in the flat fertile land of these pulp project areas. With the exception of Paraná and Pará, in all the other cases investment was on a large scale - projects larger than 800,000 tons of pulp per year, requiring at least 80,000 ha of eucalyptus plantations, plus a similar amount in conservation areas which are thus blocked for other uses by rural populations.

\section{PRIMITIVE LAND ACCESS: DYNAM ICS AND CONSEQUENCES}

\section{Contentious Expansion}

Across Brazil, forest companies are still expanding into dubious land tenure areas such as state lands ( terra devoluta) and planting eucalyptus; however, these companies are now increasingly finding themselves involved 
in land conflicts with resistance movements and the dispossessed wanting to reclaim or redistribute these state lands. Traditional populations want their lands back, supported by some state institutions within the now democratic Brazil, though the conservative and authoritarian-minded - such as the M inistry of Agriculture and M inistério da fazenda and both Military and Federal police forces - side with the companies. The federal government and state institutions have a complex role vis-à-vis tree plantations, as state institutions represent contradictory platforms of interest mediation. The main cleavage point is between a technocratic developmental ideology relying on massive corporate-state investment as the promoter of development and a grassroots ideology emphasizing local democracy and agro-ecological human capital and livelihoods to preserve the model of accumulation without dispossession (Nylund and Kröger, 2012)..$^{22}$

According to Oliveira (2011), about 60 per cent of Brazilian rural 'properties' do not have legal titling: these are illegally held and fenced lands, and legally belong to the state. Large tracts of land used for eucalyptus monocultures probably fall into this category of state land; however, it is hard to prove correct titling, as this relies on accounts of local citizens forced out of their lands, on company accounts, or on haphazardly and confusingly collected state or government data. Even so, some advances have been made by progressive prosecutors and movements within this area (Kröger, 2011).

The state, particularly in the form of state-owned companies, facilitated the flow of land and nature (natural resources) from communities to corporations. According to locals, the firm Aracruz cut tens of thousands of hectares of Atlantic rainforest in Espírito Santo in the 1970s. In 1992-3, Veracruz, predecessor of Veracel and at the time a subsidiary of the Odebrecht Group, also felled thousands of hectares of forestland. Locals and activists from the NGOs Fase, Greenpeace and Ibase to ok aerial photos, gathered personal accounts from locals, logging company contracts and other documents to demonstrate that between 1992 and 1993 Veracruz cut extensive areas of Atlantic forest within the 47,000 ha area Veracruz had acquired in 1991 from the Brazilian iron-ore company Vale do Rio Doce (CVRD, now Vale). The data were assembled by the NGOs into an extensive dossier (Fase et al., 1993) and used as a legal document. $\underline{23}$ CVRD, state-owned until 1997, was a central agent in almost all eucalyptus expansion areas, playing a key role in facilitating the conversion of state forestlands into ITP concessions operated by charcoal and pulp companies. This relationship still continues today (under Vale), for example in M aranhão, where Vale sold tens of thousands of hectares of eucalyptus plantations to Suzano, agreed to transport the pulp by the railroads it operates, and defended the pulp company against resistance. $\underline{\underline{24}}$

Besides environmental destruction, dispossession and repression of small-scale farming, debt slavery and other 'modern' forms of slavery that are dominated by the financial logic of capitalism still exist in the Brazilian countryside. Companies such as Jarí, Votorantim (now called Fibria), Suzano de Papel e Celulose (the second largest maker of paper and cardboard products in Brazil), Eucatex (the fourth-largest wood products company) and Ripasa Celulose (the fifth largest paper producer) have been accused of enslavement within the paper and pulp industry (Rose, 2005: 224-5). However, most cases of slavery are related to the production of charcoal in the northern pig-iron milling regions of the country. $\underline{25}$

The expansion of tree plantations is still subject to brutal violence and occasional murders. In February 2007, Antonio J oaquim dos Santos was murdered by an armed guard of the French-German steel producer and tree planting company Vallourec and Mannesmann (VM), on a eucalyptus plantation certified by the Forest 
Stewardship Council (FSC) in M inas Gerais. Antonio J oaquim dos Santos was a thirty-two year-old agricultural worker from the Canabrava community, which had been dispossessed of its land and denied access to basic natural resources through the expansion of tree plantations since 1975. 'Seizing Antonio Joaquim, the two armed guards hired by VM, known as C and J de Casmina, tied him up, hit him and fired two shots into his mouth in front of his daughter', according to a communiqué on 27 February 2007 by the Alert against the Green Desert Network (WRM , 2007), the most vehement opponent of tree plantation expansion. The company Aracruz, currently Fibria, has also been involved in manslaughter cases: the armed security force of Fibria killed a local villager, a young afro-Brazilian man from a Quilombola community, in Southern Bahia in M arch 2010 after he collected firewood from the plantation (Socio-Environmental Forum of the Extreme South of Bahia and the Alert against the Green Desert Network, 2010). The Quilombola community had been excluded from its lands by pulp companies which did not allow traditional wood collection on 'community lands' to continue after enclosure of the eucalyptus enclaves on these former community holdings (Ferreira, 2009). In terms of ethno-territorialism, pulp companies have been accused of racist attitudes towards indigenous and afroBrazilian communities, which is evident in many company practices and director discourses (Ferreira, 2009; M yllylä and Takala, 2010).

As a consequence, many (but not all) pulp companies face growing resistance: Veracel is currently experiencing the most pressure (see Kröger, 2011). The company claims to have incurred severe losses due to twenty-seven current occupations of their land: opponents claim the land is state land and illicitly occupied by Veracel. For example, on 4 April 2011, the landless movements occupied another land area allegedly owned by Veracel, cut down eucalyptus trees and blocked the company's access to a wide area of fibre urgently needed to run the mill. $\underline{26}$ These conflicts are having an increasingly direct impact on business profits.

The Baixa Verde camp of the M LT (M ovement for Land Liberation) near to Eunápolis is another example. In the 1960s and 1970s, the area's forestland was cleared and settled by cattle ranchers, wood loggers and smallscale tenant farmers, and part of the land was registered as private property. However, the land had terra devoluta status, that is, it was state land to be used for parcelling for farming families, as later confirmed by the relevant authorities of Bahia, the Coordination of Agrarian Development (CDA). In 2000, the alleged owner, Veracel, forced the settlers to move and the area was planted with eucalyptus. ${ }^{27}$ Eucalyptus plantations were quickly extended to the settlement lands. By 2006, the area was completely occupied by eucalyptus, which had even been planted on a communal cemetery, without the required permits and without respect for the local community. All the villagers' houses were demolished and the residents were forced to live in poor urban conditions. M LT coordinators united desperate families ready to return to the countryside, and during a 'blitz' occupation in November 2008, the locals returned and took over the area where the company grew eucalyptus. Black plastic bag shelters housed dozens of families, waiting for the return of lands which, having officially been declared as state land, could not be appropriated by the company for its own use. According to the CDA, the land in question (Fazenda São Caetano, an area of 1,333 ha) does not belong to Veracel, even if the company alleges it does: this state land is to be delivered back to the farmers in the form of a settlement.

\section{THE FINANCIAL LOGIC OF EXPANSION AND EXCLUSION}


Not all tree plantation expansion involves dispossession, corruption, repression, slavery and murder. Some expansion occurs in the form of business transactions where land changes hands through markets, although some 'proprietors' (land grabbers) sell their land to pulp companies illegally.

In the early phase of expansion during the military dictatorship, outright fraud in land sales was common, and the main reason for smallholders to sell was the promise of getting legal land titles promised by brokers. There has been a constant effort since the dictatorship to seduce rural families to move to cities: the 'brokers' involved typically argued that life would be better in the city, particularly for the children. They offered to take care of the whole process, legalizing land for dwellers that had a right to it by law, but in fact stealing land by demarcating a smaller area for the families than they actually had rights to, and then selling the stolen land to pulp companies. If there were no legal documents showing land ownership, the 'right to use' land was sold. If the rural dweller did not want to sell the 'right to use' land and plant on it, then the company asked for land directly from the state (Ferreira, 2009).

In the area where Veracel is situated, as in most other expansion areas, large unproductive landowners used (and still use) the arrival of the pulp company to liberate themselves profitably from the historical burden of land grab, turning the grabbed land into cash by selling it and thus escaping the risk of land appropriation. $\frac{28}{2}$ Usually, the act of selling land is legally endorsed, even though the land might be state land. It was beyond the scope of this research to gather sufficient information from the thousands of smallholders who had sold their lands in the expansion areas to analyse systematically the reasons for contemporary selling: however, the few interviews gathered illustrate individual reasons for selling, and these are discussed below. Those most aware of the rural exodus phenomenon, such as public officials and rural organization leaders, were interviewed to get a general picture.

Some of these small-scale sellers, as well as rural workers whose tenant relations with the large farms where they used to live and work are severed when the owners sell lands, end up in landless camps or settlements, although most find themselves in urban favelas. No official records exist of their numbers, but visiting dozens of urban and rural peripheries in almost all eucalyptus-expansion areas allowed for personal observations, and interviews illustrated the causal mechanisms. Some sell their land because they want to, and understand the results of the decision, i.e. the difficulty or impossibility of returning to the land as a farmer. Others sell because life becomes increasingly difficult for them, isolated in a sea of silent eucalyptus trees, as often happens in pulp and charcoal investment areas. In charcoal areas, pollution is another reason to move out, and complaints about water depletion were documented by the author at almost all rural communities close to eucalyptus.

For people whose neighbours have moved out, the pressure to follow is great. The main theme that surfaced in the fieldwork was the same as in the 1970s and 1980s: farmers were seduced to sell their land for the sake of a better future in a city, particularly for their children, rather than on a farm which is increasingly surrounded by walls of eucalyptus and with fewer neighbours and public services. This domino effect was the main reason for 'voluntary' contemporary selling. $\frac{29}{-}$ Tree plantation companies recognize this: they benefit from a domino mechanism of buying one farm and then waiting for the others to fall. The effect is revealed in the personal histories of people faced with eucalyptus plantations in their area. Many rural residents do not want to live next to eucalyptus plantations, as they perceive them to be ugly and potentially dangerous. People are 
concerned that the pesticides and fertilizers used will spread to their lands and water, and that eucalyptus offers excellent hideouts for criminals. Eucalyptus is aesthetically ugly to many and is associated with subordination. For the local MST activists, the plant represented 'multinational companies with money' and 'capital, which condemns', and the monoculture is seen as a 'Babylon of capital'. $\underline{30}$ Rows of orderly trees blocking the extended view do not fit traditional pastoral ideals.

Besides the isolation, a further reason for selling land to companies is debt. Farmers take extensive risks on 'Green Revolution' agriculture, where financial logic rests uneasily with the volatility of agriculture. Soils may erode and the intensive use of fertilizers and herbicides (often demanded by lending institutions) harm the land; as a result, farmers' incomes drop, and they often become bankrupt; banks then foreclose on the lands, and the plantation industry buys them. The debt problem is intensified by Brazil having one of the world's highest interest rates, which means that farmers have little time to look for the best offer when the downturn comes. In comparison to agribusiness, the access to credit for non-corporate agriculture is still limited, even though the Ministry of Agrarian Development has given more credit to small-scale farmers since the mid-1990s (Wolford, 2010).

\section{Exclusion by Rising Land Prices}

Driven by the financial logic of cost minimization and productivity maximization, pulp companies buy, rent and outsource lands through technologically developed methods. The productive variables in the establishment of eucalyptus plantations include not only land, but also water availability. There are many such issues that need addressing; technical personnel appear more aware of these and more willing to look for solutions than company directors, who are cautious about their public image and try to hide any kind of misconduct. ${ }^{31}$ 'We have to be more conservation-minded', said one unnamed technician working as a planner for land access for Stora Enso, a Finnish-Swedish paper company. $\underline{32}$

Yet a rise in land prices is causing a pre-emptive barrier to land distribution attempts. $\underline{33}$ Land prices in Brazil have soared dramatically. $\frac{34}{-}$ In 2006, the land price in Bahia's eucalyptus zones was four to six times higher than a few years previously. ${ }^{35}$ Field research interviews with company officials and locals revealed that land prices rose from 200 reais per hectare to 6,000 reais per hectare in pulp project areas in the ten years up to 2006. Companies are willing to pay this (if they cannot get the land for free by grabbing), as they need all possible land within $100 \mathrm{~km}$ of the pulp mill; beyond this area, the logistical costs are much higher for the corporations. It is this financial-technical logic that sets the tone for investment, not the demands of local populations. According to paper bosses and engineers, it is cheaper for companies to build a large pulp mill in one location, reaping economies of scale in saved steel and machinery costs: the mill can be expanded later, creating even more intensive monoculture landscapes.

According to a local NGO (Research Centre for the Development of the Extreme South of Bahia, CEPEDES), the municipality which experienced the greatest rural exodus in Brazil in 2005 was Eunápolis. $\frac{36}{}$ Land prices there have increased ten-fold, according to ASPEX, the local organization of eucalyptus contract growers. Thousands of small-scale farmers became unemployed and migrated to cities in 1992-2005 due to Veracel's land acquisitions and the construction of the factory (fieldwork observation, June 2004; Koopmans, 2005). In general, in many places across Brazil large-scale land acquisition during the past decade rendered family-sized 
and medium-sized food-producing agricultural units unviable and made agrarian reform difficult, if not impossible, as the state land reform agency could not compete with industry in the buying of land. $\frac{37}{3}$

In the $100 \mathrm{~km}$ perimeter around pulp projects, land reform and tree plantations struggle for good land, not because land is lacking, but because increases in the price of land mean that landowners, principally cattle ranchers, are unwilling to sell their land for INCRA's agrarian reform at the lower price offered by the state. The prospects for land reform are further weakened by the introduction of temporary and outsourced wage work that fosters the creation of rural landless would-be workers instead of a peasant class controlling or owning lands, based on family and collective farming. Sassen (2010) argues that in primitive accumulation traditional capitalisms are destroyed to transnationalize natural resources. In the mix of market-based agrarian policies and violent forms of land access that are the hallmark of the advance of Brazilian eucalyptus primitive accumulation, landless populations are the losers as the financial logic offers corporations more room to manoeuvre.

\section{CONCLUDING REMARKS}

The advance of eucalyptus is an example of the current phase of global capitalism, which is dominated by financial logic and exploits resource peripheries (Sassen, 2010), a process Harvey (2003) calls accumulation by dispossession. The rise of agribusiness and new pulp investments provide empirical evidence to support the claim that Brazilian land is increasingly considered a financial asset, especially in the government and business sectors but also in many rural communities, through the sale of land. Corporate land access and expansion take place through a mixture of violence and financial mechanisms, most of which lead to capital accumulation through direct or indirect dispossession of traditional communities.

Fast-wood expansion is carried out by traditional forms of primitive accumulation (in which peasants are expelled, commons enclosed, alternative modes of wood production suppressed, neo-colonial type settings such as free-trade areas established, and even slavery used in some cases), as well as by new mechanisms of accumulation by dispossession (in which tree variants are cloned and patented, the need of rural and industrial labour is minimized through mechanization, and major state and multinational banks support the process by lending to large-scale corporations or investing in resource extraction that either directly or indirectly displaces traditional forms of capitalist and non-capitalist communities). There have been isolated attempts in Brazil to promote accumulation without dispossession, but it is hard to see how they could succeed without considerable changes to the agrarian structure, government/corporate policies, the general political economic dynamics behind industrial plantation expansion, and the expansion model in which the majority of land is corporate-owned or controlled. Entrenched power relations in rural Brazil have instead contributed to the strengthening of primitive accumulation via new mechanisms of accumulation by dispossession, providing a coherent explanatory framework for contemporary plantation expansion.

Systematic comparison of pulp eucalyptus expansion across Brazil, the presence or absence of five signs of primitive accumulation, and general data on land prices and differences in corporate land access type (Tables 1 and 2) suggest there are differences across contexts and/or companies. Signs of accumulation by dispossession were in general more common than their opposite, i.e. accumulation without dispossession. The large-scale monoculture-based pulp investment model correlated with primitive accumulation. The lower the pasture land price in the state, the higher the dispossession of rural populations has been. The context heightened the 
impact: in general, the more companies outsourced or rented land instead of directly owning it, the fewer signs there were of primitive accumulation. However, even though this could imply wider distribution of income and decreases in accumulation by dispossession, a more detailed look at the specifics of partnership and contract eucalyptus farming is needed in order to track particular causalities and developmental gains or opportunities. In many places, contract planting has been a middle-class business strongly controlled by companies, with peasants excluded or lacking autonomy.

The eucalyptus industry is exerting growing power over markets, national governments and states. Companies such as Stora Enso are such large players that they can create markets through constructing huge pulp mills, such as Veracel: as one wood supply executive from Stora Enso expressed it, 'I am the market'. The new Brazilian pulp giant Fibria has considerable power in Brazil, as have had the steel giant Vale and local land markets, in the expansion of eucalyptus monocultures. The state plays a key role in giving preferential land titles and access to eucalyptus companies instead of peasants. Despite broad electoral campaign support from the pulp companies, $\underline{38}$ however, Brazilian state actors do not totally favour industrial plantations. This is partly explained by the companies' own mistakes in running plantation operations and advocating the expansion of plantations in dubious ways, as shown by several disastrous cases. Yet, there is still room for things to get

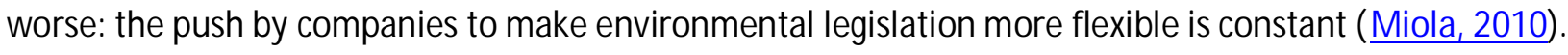

The dangers represented by eucalyptus expansion accompanied by dispossession of rural populations, violence, environmental degradation, and decreasing employment are clear, and speak to a wider global phenomenon. In the words of Li (2011: 296), 'the truncated trajectory of agrarian transition in much of the global South, one in which there is no pathway from country to city, agriculture to industry, or even a clear pathway into stable plantation work that pays a living wage, is the crucial scale at which to review the land grab debate'. A patch of would-be eucalyptus monoculture land which remains in the hands of a peasant or indigenous tribe is a crucial safety net in the context of global capitalism where off-farm jobs that pay a living wage are scarce. This context both explains, and promises, increasing resistance. M eanwhile, plantations will continue to expand around the country.

Footnotes

- 1

This is due to the rest of the world becoming increasingly reliant on Brazilian commodity and agricultural production. Brazil ranks first in the export and production of several food commodities, such as orange juice (80 per cent) and ethanol (51 per cent), and ranks in the top four for the export and production of many other commodities (USDA, 2005).

- 2

Industrial plantations are defined as large-scale, non-family farms of four rural modules or larger. The size of rural modules varies according to municipality and state; four rural modules is maximally 440 ha, but more typically 20 ha.

- 3 
Brazil is the primary country globally in the planting of short-rotation Eucalyptus grandis and hybrids (Cossalter and Pye-Smith, 2003: 7).

- 4

I have argued elsewhere that the reason for this continuing state support to 'national champions' such as pulp companies is that the Brazilian government has engaged on a strategy of neo-mercantilist capitalism, as a way of increasing the clout of the most powerful national economic and political groups in the international political economy (Kröger, 2012).

- 5

The main field research and interview areas and periods were: Southern Bahia (June 2004; July 2006; June 2008; April 2011); Southern Rio Grande do Sul (May 2008); São Paulo (September 2006; June 2008); Eastern Rio de Janeiro (M arch 2004); Pará (September 2005; M arch 2007; February 2011); and Western M aranhão (March 2011). Most attention was paid to Bahia, the state with most tree plantations (527,000 ha in 2010) and Rio Grande do Sul, which represented the most ambitious expansion plans in 2006-8. M inas Gerais and M ato Grosso do Sul were not covered by field research.

- 6

Accumulation without dispossession can also be accumulation through productive investment, which still relies on individual ownership and labour exploitation (albeit to a lesser extent than primitive accumulation), even though forceful expulsion of peasant populations does not occur.

- 7

See the CPT website: http:// www.cptnacional.org.br

- 8

A prevalent land acquiring mechanism - and the cause of many Brazilian land conflicts - is grilagem (illegal land grab), in which a grileiro falsifies documents to illegally appropriate land. The grileiro is normally a powerful patron with a prominent political, legal and economic position. Grileiros use different names and register smallholdings as individual farms, even though they belong to one family or enterprise and thus form a latifúndio farm (Asselin, 2009).

- 9

$\mathrm{CPI}$ is a principal way of doing politics and investigating wrongdoings in Brazil, and is the focus of major political debates.

- 10

Although there were some large state projects as well, such as the Projeto Grande Carajás in the Eastern Amazon (Asselin, 2009). 
- 11

M ost plantations in Brazil are within a $100 \mathrm{~km}$ radius of the mill; shipping of pulp is cheap in comparison to paper.

- 12

Row spacing, planting techniques and forest management have raised productivity in Brazil from 14 to 40 cubic meters per hectare per year between the 1970s and the present (Piketty et al., 2009: 181).

- 13

The 1996 Law of Kandir (Lei Complementar No. 87/96), passed to boost exports of commodities earning hard currency for Brazil, decreed that pulp companies do not have to pay the ICM Staxes (a tax on the circulation of goods and services), which is one of the principal revenue sources of Brazilian state government budgets ( 1 oly, 2007: 41).

- 14

Information provided in company annual reports and compared by Nylund and Kröger (2012), suggests a typical profit margin for a new pulp venture of about 40 per cent. According to Lyytinen and Nieminen (2009): 'In 2008 the Veracel mill [joint venture of Stora Enso and Fibria] made EUR 123 million in profits, before interest, write-offs, and taxes. This was an astounding 43 per cent of the EUR 238 million turnover of Veracel'.

- 15

In practice, governments have offered extensive incentives and eased land access for entrepreneurs to establish tree plantations (Bull et al., 2006).

- 16

Capital inputs were minimal for landowners, given the banking arrangements whereby they received loans for silviculture with no borrowing costs ( $0 \%$ interest rate). The costs to the landowner would relate to the capital in the land purchase or the opportunity costs of capital. The rates of return for pine were lower because pine trees have a longer rotation age and lower yield.

- 17

The MMA has been one of the few state institutions, along with the Public M inistry and the Ministry of Agrarian Development, that have at some times and in some places been critical towards the expansion.

- 18

The statistics on annual lending by BNDES are publicly available at:

http://www.bndes.gov.br/SiteBNDES/bndes/bndes_pt/Institucional/BNDES_Transparente/Estatisticas_Operaci onais/setor.html. The Bank calculates the annual expenditure of resources from the BNDES System by sectors, including the paper and pulp industry. 
- 19

Bracelpa is the lobby organization of the paper and pulp industry in Brazil, with a website offering data freely. The figures it gives are based on information it has received from its member companies. Thereafter, the figure does not include all eucalyptus expansion in Brazil (non-member companies and charcoal eucalyptus are excluded).

- 20

Correio Braziliense,'Demissões nas papeleiras', 4 May 2009.

- 21

The last rural census in Brazil was conducted in 2006.

- 22

There is a wide variety of alternative practices offered by the latter group, some more 'socialist' in orientation (such as MST, the Brazilian Landless M ovement, settlements) and others more 'green capitalist' (such as forest communities and their advocates wishing to capitalize on standing forest through the carbon markets). The dynamics and blurring of the lines between peasants and agrarian capitalism are also present in other sectors, such as biofuels. For Fernandes et al. (2010: 816), even though some agrarian reform communities have benefited from entering into agrarian capitalism through agrofuel projects, the state/industry-peasant relation is still hegemonic, as 'no single production or nutritional policy in Brazil today has been developed in conjunction with or left under the administrative control of peasant organizations'. In the case of eucalyptus plantations, attempts to incorporate peasant communities as producers have been rare, and have either been resisted outright, interrupted by state authorities as violating settlement legislation, or have failed in other ways. Most non-corporate tree plantation capitalism is carried out by middle-class, middle-sized farmer entrepreneurs closely tied to the industry. For further discussion on the cleavage between traditional communities and developmentalist projects, see Zhouri (2010).

- 23

After denunciations, the Minister of the Environment at the time, Fernando Coutinho Jorge, blocked the project from turning Atlantic forest into eucalyptus plantations, demanding that the federal environmental agency conduct studies prior to restarting the project. However, the state agency delegated the task to a private forestry consulting company, the Finnish Jaakko Pöyry, which, unsurprisingly, found no problems, and the project continued (Silvestre, 2008).

- 24

This paragraph is based on interviews and field research in the area in M arch 2011.

- 25

Interview with Felicio Pontes, Federal Public Prosecutor, Pará, Belem (M arch 2011). 
- 26

See press releases at http:// www.mst.org.br, and http:// www.veracel.com.br

- 27

Interviews with residents of the M LT Baixa Verde camp (26 M arch 2011).

- 28

Interviews with Arnoldo and Eduardo Prado, medium-scale landowners and eucalyptus cultivators in Veracel's outgrower programme (26 M arch 2011); interview with the coordinating prosecutor Silva Neto, Eunápolis (27 March 2011).

- 29

However, smallholder land selling constitutes only a few per cent of the overall land acquisition by companies, according to almost all those interviewed (activists, public officials, industry representatives, contract eucalyptus farmers): the main mechanism is large-scale land transaction involving cattle ranchers and possession of public lands.

- 30

Interviews with landless movement militants, Eunápolis (June 2006).

- 31

Interviews with paper company personnel (2004-2011).

- 32

Interview Rio Grande do Sul (May 2008).

- 33

Interviews with land institute officials (2006-2011).

- 34

Between 2006 and 2008, land prices in Brazil increased due to the general commodity boom in world markets. In the south of Brazil, where three new huge pulp projects (Stora Enso, Votorantim, Aracruz) started to buy land for eucalyptus, land prices rose by 43.3 per cent. In the south-east, prices rose by 36 per cent, and in the north-east by 43.9 per cent (Reuters News, 2009).

- 35

Interviews with trade union leaders at the STR Eunápolis (2006).

- 36 
Interview with Ivonete Souza, CEPEDES, Eunápolis (June 2008); also extensive research by Souza and Overbeek (2008).

- 37

Interview with M ozar Dietrich, Superintendent of INCRA in Rio Grande do Sul (M ay 2008).

- 38

Based on research of public election financing data offered online by the Supreme Electoral Tribunal (http:// www.tse.gov.br), all pulp companies financed political campaigns in the 2006 elections. After adding up the sums from the official Supreme Electoral Court statistics, Aracruz donated a total of 5,523,353 reais (about US\$2.8 million in 2006) to representative candidates in the 2006 elections and Votorantim Celulose e Papel $\mathrm{S} / \mathrm{A}$ made donations of $1,657,379$ reais (about US $\$ 840,000$ in 2006).

\section{REFERENCES}

ABRAF (2011) 'Anu'ario estat 'istico da ABRAF 2011 ano base 2010' ['Yearly Statistics of ABRAF, Based on Year 2010)']. Bras'ilia: ABRAF.

Arrighi,G., N. Aschoff and B. Scully (2011) 'Accumulation byDispossession and its Limits: The Southern African Paradigm Revisited', Studies in Comparative International Development 45(4): 410-38.

Arruda, M., H. Souza and C. Afonso (1975) Multinational Corporations and Brazil. Toronto: Latin America Research Unit.

Asselin, V. (2009) Grilagem: Corrupc, `ao e viol`encia em terras do Caraj’as [Illegal Land Grabbing:

Corruption and Violence in the Lands of Caraj'as]. Imperatriz: 'Etica (2nd edn).

Barros, J. (2008) 'O papel `ao da Suzano no Piau'ı' ['The Fiasco of Suzano in Piau'ı'].

Rede Ambiental do Piau'ı. http:// www.portaldomeioambiente.org.br/pma/index.php?option= com_content $\&$ view $=$ article $\&$ id $=717$

BNDES (2009) ‘Desembolso anual do sistema BNDES' ['Annual Lending by the BNDES

System']. www.bndes.gov.br/estatisticas

Bracelpa (2009) 'A' rea total reflorestada em 31/12/2007' ['Total Area Reforested on 31 January 
2007]. http:// www.bracelpa.org.br/bra/estatisticas/pdf/anual/reflo_01.pdf

Bracelpa (2010) 'Relat'orio Anual 2009/2010' ['Annual Report 2009/2010']. http:// www.

bracelpa.org.br/bra2/ sites/ default/ files/ estatisticas/rel2009.pdf

Brand ao, C. (2007) 'Tempos e espac os nos mundos rurais do Brasil' ['Times and Spaces

in the Rural Worlds of Brazil'], Ruris 1(1). http:// www.ifch.unicamp.br/ceres/037-064-

carlos_rodrigues.pdf

Bull, G. et al. (2006) 'Industrial Forest Plantation Subsidies: Impacts and Implications', Forest Policy and Economics 9(1): 13-31.

Carrere, R. and L. Lohmann (1996) Pulping the South: Industrial Tree Plantations and theWorld Paper Economy. London: Zed Books.

Cossalter, C. and C. Pye-Smith (2003) Fast-Wood Forestry: M yths and Realities. Jakarta: Center for International Forestry Research.

CPT (2011) 'S'intese Terra - 2009/2010'. 7 April. http:// www.cptnacional.org.br/index.php?

option $=$ com_jdownloads\& $/$ temid $=23 \&$ view $=$ finish $\&$ cid $=211 \&$ catid $=37$

De'Nadai, A., W. Overbeek, and L. Soares (2005) Promises of Jobs and Destruction of Work:

The Case of Aracruz Celulose in Brazil. London: WRM .

The Economist (2010) 'Nest Egg or Serpent's Egg?', The Economist 5 August.

Fase / Greenpeace / Ibase (1993) ‘Dossi^e Veracruz' ['Veracruz Dossier']. Rio de Janeiro: Fase.

Fernandes B., C. Welch and E. Constantino (2010) 'Agrofuel Policies in Brazil: Paradigmatic

and Territorial Disputes', Journal of Peasant Studies 37(4): 793-819.

Ferreira, S. (2009) '“Donos do lugar": a territorialidade quilombola do S^ape do Norte - ES'

['“Lords of Place”: The Quilombolo Territoriality in S^ape do Norte, Esp'irito Santo'). PhD

dissertation, UFF, Niter'oi.

Industrial Tree Plantations and Dispossession in Brazil 971

Fingerl, E. and J. Filho (1998) 'The Brazilian Pulp and Paper Industry Investment Requirements'.

BNDES. www.bndes.gov.br/english/studies/r_03_98i.pdf 
Finnish Forest Industries Federation (2009) 'The Forest Cluster - A Network of Expertise and Business Activities'. Helsinki: Forest Industries Statistics Service.

Gasques, J., E. Bastos and C. Valdes (2008) 'Prec os da Terra no Brasil' ['Land Prices in Brazil']. Rio Branco: SOBER. http:// ageconsearch.umn.edu/bitstream/106106/2/587.pdf Gerber, J. (2010) 'Conflicts over Industrial Tree Plantations in the South: Who, How and Why?', Global Environmental Change 21(1): 165-76.

Hart, G. (2002) Disabling Globalization: Places of Power in Post-Apartheid South Africa. Berkeley, CA: University of California Press.

Harvey, D. (2003) The New Imperialism. Oxford: Oxford University Press. IBGE (2006a) 'Confronto dos Resultados dos Dados Estruturais dos Censos Agropecu'arios 1970-2006' ['Summary of the Results of Structural Statistics in Agricultural Census']. http://www.ibge.gov.br/graficos_dinamicos/censo_agro/default.htm IBGE (2006b) ‘Censo agropecu'ario 2006. Tabela 1.1 - Utilizac, `ao das terras nos estabelecimentos, por tipo de utilizac, `ao, segundo a agricultura familiar, Brasil - 2006' ['Census of Agriculture. Land Use in Establishments by Type of Use, According to Family Farming']. Rio de Janeiro: IBGE. Jackson, R. et al. (2005) 'Trading Water for Carbon with Biological Carbon Sequestration', Science 310: 1944-7.

Jepson, W.E. (2006) 'Private Agricultural Colonization on a Brazilian Frontier, 1970-1980', Journal of Historical Geography 32(4): 839-63.

Joly, C. (2007) ‘Especializac, `ao produtiva do territ’orio e o circuito espacial produtivo de celulose em Eun'apolis - BA' ['Specialization of the Territory and Spatial Productive Circuit of Pulp in Eun'apolis - BA']. Master's thesis, USP, Sªo Paulo.

Juvenal, T. and R. M attos (2002) 'O setor de cellulose e papel. BNDES 50 anos - hist'orias setorais' ['The Paper and Pulp Sector. BNDES 50 Years - Sectorial Histories']. Rio de Janeiro: BNDES. http://www.bndes.gov.br/SiteBNDES/ export/sites/default/bndes_pt/ 
Galerias/Arquivos/conhecimento/livro_setorial/setorial04.pdf

Kenfield, I. (2007) ‘Taking on Big Cellulose: Brazilian Indigenous Communities Reclaim their Land', NACLA Report on the Americas November/December.

Kingstone, P. (1999) Crafting Coalitions for Reform: Business Preferences, Political Institutions, and Neoliberal Reform in Brazil. Pennsylvania, PA: The Pennsylvania State University Press. Koopmans, P.J. (2005) Al'em do eucalipto: o papel do extremo sul [After Eucalyptus: The Role of Extreme South]. Teixeira de Freitas: CDDH.

Kr"oger, M. (2011) 'Promotion of Contentious Agency as a Rewarding M ovement Strategy:

Evidence from the MST-Paper Industry Conflicts in Brazil', J ournal of Peasant Studies 38(2): $435-58$.

Kr"oger, M. (2012) 'Neo-mercantilist Capitalism and Post-2008 Cleavages in Economic Decisionmaking Power in Brazil', Third World Quarterly 33(5): 887-901.

Kr"oger, M. and J.-E. Nylund (2012) ‘The Conflict over Veracel Pulpwood Plantations in Brazil: Application of Ethical Analysis', Forest Policy and Economics 14(1): 74-82.

Kudlaviz, M. (2011) 'Din ámica agr'aria e a territorializac, „ao do complexo celulose/papel na microrregi ₹ao de Tr^es Lagoas/M S' ['Agrarian Dynamics and Territorialization of the Pulp/Paper Complex in the Micro-region of Tr^es Lagoas/MS']. Master's Thesis in Geography, UFM S, Tr^es Lagoas.

Kuisma, M., A. Henttinen, S. Karhu and M. Pohls (1999) The Pellervo Story: A Century of Finnish Cooperation, 1899-1999. Helsinki: Pellervo.

Lehtinen, A. (2002) 'Globalization and the Finnish Forest Sector: On the Internationalization of Forest-industrial Operations', Fennia 180(1-2): 237-50.

Lessa, C. (2010) 'Empresa privada e o Projeto Nacional' ['Private Company and the National Project'], Valor Econ^omico 22 December (Opinion).

972 M arkus Kr"oger

Li, T. (2011) 'Centering Labor in the Land Grab Debate', Journal of Peasant Studies 38(2): 
281-98.

Lyytinen, J. and T. Nieminen (2009) 'Stora Enso's Jackpot', Helsingin Sanomat 30 August. M archak, P. (1995) Logging the Globe. Montreal: M cGill-Queen's University Press.

M iller, S. (2007) Environmental History of Latin America. Cambridge: Cambridge University Press.

Miola, I. (2010) ‘Between Strictness and Flexibility: How Law Enables the Globalization of the Pulp and Paper Industry', El Norte - Finnish Journal of Latin American Studies 5. http://www.elnorte.fi/archive/2010-5/2010_5_elnorte_miola.pdf M M A (2005) 'Temas Conflituosos Relacionados `a Expans`ao da Base Florestal Plantada e Definic, „ao de Estrat'egias paraM inimizac, ”ao dos Conflitos Identificados' ['Conflictive Themes Related to the Expansion of Planted Forest Base and Definition of Strategies to Minimize the Identified Conflicts']. Bras'ılia: Ministry of the Environment (M M A).

Myllyl”a, S. and T. Takala (2011) 'Leaking Legitimacies: The Finnish Forest Sector's Entanglement in the Land Conflicts of Atlantic Coastal Brazil', Social Responsibility Journal 7(1):

$42-60$.

Nylund, J. (2009) 'Forestry Legislation in Sweden'. Report No. 14. Uppsala: The Swedish University of Agricultural Sciences, Department of Forest Products.

Nylund, J. and M. Kr"oger (2012) 'Cleavage in the Understanding of Sustainability: Sustainable Pulp Industry versus Sustained Local Livelihood', Scandinavian Journal of Forest Research 27(2): $229-40$.

Oliveira, A. (2011) 'E uma mentira dizer que no Brasil a terra 'e produtiva' ['It is a Lie to Say that in Brazil the Land is Productive']. Special interview with Ariovaldo Umbelino by M 'arcia Junges. IHU Online 10 January.

Piketty, M., M. Wichert, A. Fallot and L. Aimola (2009) 'Assessing Land Availability to Produce Biomass for Energy: The Case of Brazilian Charcoal for Steel M aking', Biomass and Bioenergy 33(2): 180-90. 
Puppim de Oliveira, J. (2008) 'Property Rights, Land Conflicts and Deforestation in Eastern Amazonia', Forest Policy and Economics 10(5): 303-15.

Reuters News (2009) ‘Prec ,o da terra no Brasil recua com sa'ida de compradores' ['Land Price Drops in Brazil due to the Exit of Buyers']. 21 January 2009.

Rose, R. (2005) The Unpast: Elite Violence and Social Control in Brazil 1954-2000. Athens, $\mathrm{OH}$ : Ohio University Press.

Sassen, S. (2010) 'A Savage Sorting ofWinners and Losers: ContemporaryVersions of Primitive Accumulation', Globalizations 7(1): 23-50.

Schwartz, S.B. (1984) 'Colonial Brazil, c. 1580-c. 1750: Plantations and Peripheries', in Leslie Bethell (ed.) Colonial Latin America, pp. 423-99. Cambridge: Cambridge University Press.

Scott, J.C. (1998) Seeing Like a State: How Certain Schemes to Improve the Human Condition Have Failed. New Haven, CT and London: Yale University Press.

Silvestre, L. (2008) 'Justic, a condena Veracel Celulose por desmatar 96mil ha de Mata Atl`antica' ['Justice Sentences Veracel Celulose for Deforesting 96,000 ha of Atlantic Forest'], Brasil de Fato 14 August: 4.

Socio-Environmental Forum of the Extreme South of Bahia and the Alert against the Green Desert Network (2010) 'Armed Security Force of Fibria (Aracruz) Kills Local Villager in Bahia'. Press release, $23 \mathrm{M}$ arch.

Souza, I. andW. Overbeek (2008) Violac, „oes socioambientais promovidas pela Veracel Celulose, propriedade da Stora Enso e Aracruz cellulose: Uma hist'oria de ilegalidades, descaso e gan^ancia [Socio-environmental Violations Committed by Veracel Celulose, Property of Stora Enso and Aracruz Celulose: A History of Illegalities, Neglect and Greed]. S ao Paulo: CEPEDES/Express ^ao Popular.

Teixeira, F. and O. Guerra (2000) ‘50 Anos da Industrializac, `ao Baiana: do enigma a uma din ^amica ex'ogena e espasm 'odica' ['50 Years of Bahian Industrialization: From Enigma to 
an Exogenous and Spasmodic Dynamics'], Bahia An'alise \& Dados 10: 87-98.

Industrial Tree Plantations and Dispossession in Brazil 973

USDA (2005) 'USDA's Foreign Agricultural Service and Global Trade Information Services

Data'. www.ers.usda.gov/AmberWaves/November06/Features/Brazil.htm

Wolford, W. (2010) 'Participatory Democracy by Default: Land Reform, Social M ovements and

the State in Brazil', J ournal of Peasant Studies 37(1): 91-109.

WRM (2007) 'Armed Militia of VM - Vallourec M annesmann - Cowardly M urdered

Geraizero of the Canabrava Community'. http:// www.wrm.org.uy/countries/Brazil/

armed_militia.html

Zhouri, A. (2010) '“Adverse Forces” in the Brazilian Amazon: Developmentalism versus Environmentalism and Indigenous Rights', The Journal of Environment \& Development 19(3):

252-73.

Markus Kröger is at the University of Helsinki, Department of Political and Economic Studies (Political Science, Unioninkatu 37, PO Box 54, 00014 University of Helsinki, Helsinki, Finland; e-mail: markus.kroger@gmail.com). He is currently an Academy of Finland Postdoctoral Researcher, studying natural resource politics and the global political economy, particularly the role of social movements in forestry and mining conflicts in Brazil and India.

I would like to thank the anonymous reviewers for excellent recommendations which substantially improved this article. I am also grateful to the editors, all those helping to conduct the field research in Brazil and giving their time for interviews, and to Peter Evans, Ruth Reitan, Sid Tarrow, Jan-Erik Nylund, Adalberto Franklin,Winnie Overbeek, Teivo Teivainen and Jussi Pakkasvirta. 